NOTE

\title{
Effect of chronic Taura syndrome virus infection on salinity tolerance of Litopenaeus vannamei
}

\author{
Jeffrey M. Lotz ${ }^{1,2, *}$, Lesber Salazar Anton ${ }^{1}$, M. Andres Soto ${ }^{1}$ \\ ${ }^{1}$ Department of Coastal Sciences, The University of Southern Mississippi, Gulf Coast Research Laboratory, PO Box 7000, \\ Ocean Springs, Mississippi 39566-7000, USA \\ ${ }^{2}$ Present address: Department of Biology, Texas A\&M University at Kingsville, Kingsville, Texas 78363, USA
}

\begin{abstract}
Taura syndrome virus (TSV) is one of the most important shrimp viruses affecting farmed shrimp worldwide. After an acute phase during which the likelihood of mortality is elevated, infected shrimp enter a chronic phase during which shrimp appear to resume normal behavior and display no gross signs of infection. This study was designed to determine if chronically TSV-infected shrimp Litopenaeus vannamei are compromised by the infection. Specifically we investigated whether chronically infected shrimp could tolerate a drop in salinity as strongly as uninfected shrimp. The study consisted of 3 trials that compared survival of uninfected and chronically TSV-infected $L$. vannamei after drops in salinity from $24 \mathrm{ppt}$ to salinities varying from 18 to $0 \mathrm{ppt}$. Logistic regression detected a significant effect of TSV infection on survival of chronically infected shrimp $(\mathrm{p}<0.05)$. Salinity drops from $24 \mathrm{ppt}$ to 3 and $6 \mathrm{ppt}$ resulted in statistically different survivals $(p<0.05)$. Survival rates were similar among groups for salinity drops to greater than 6 ppt or less than 3 ppt. Salinities at which $50 \%$ of the shrimp died $\left(\mathrm{LC}_{50}\right)$ were $3.06 \mathrm{ppt}$ for the uninfected and $6.65 \mathrm{ppt}$ for the chronically infected groups. Moreover, histopathological analysis of chronically infected shrimp that were moribund or recently dead showed no signs of having reverted to the acute stage of the disease. These results suggest that chronically infected shrimp are not able to tolerate a salinity drop as strongly as uninfected shrimp.
\end{abstract}

KEY WORDS: Taura syndrome virus $\cdot$ Litopenaeus vannamei $\cdot$ Shrimp $\cdot$ Virus

-Resale or republication not permitted without written consent of the publisher

\section{INTRODUCTION}

Taura syndrome virus (TSV) is among the most serious pathogens affecting shrimp farming worldwide (Lightner 1999). Since 1992, TSV outbreaks have been reported from most of the shrimp farming countries of Latin America and in the United States from the states of Texas, Hawaii, Florida, and South Carolina (Hasson et al. 1999a). Moreover, TSV has spread to Asia, where it has caused severe mortality in cultured Litopenaeus vannamei (Yu \& Song 2000).

TSV infections in Litopenaeus vannamei can be categorized into 1 of 4 kinds: prepatent, acute, transition, and chronic (Hasson et al. 1999b, Lotz et al. 2003).
Prepatent infections are asymptomatic and last from 2 to $5 \mathrm{~d}$. During this time the virus multiplies, eventually causing a symptomatic acute infection. Acute infections may last from 1 to $10 \mathrm{~d}$, during which time the host has an increased probability of mortality and displays characteristic histological tissue lesions. Transition infections last about $5 \mathrm{~d}$, while shrimp destined to survive resolve the acute lesions and form lymphoid organ spheroids. Chronic infections are harbored by surviving shrimp and may last the remainder of the host's life. Chronically infected shrimp appear normal, have a reduced likelihood of mortality, resume normal behavioral patterns, and complete resolution of the acute lesions. It is unclear at this time whether chroni- 
cally infected shrimp are adversely affected by the infection. Therefore we performed a study to determine the effect of chronic TSV infections on the capability of $L$. vannamei to tolerate rapid drops in salinity.

\section{MATERIALS AND METHODS}

Kona stock of Litopenaeus vannamei were obtained from the Oceanic Institute in Hawaii. The stock is part of the United States Marine Shrimp Farming Program (USMSFP) and originated as postlarvae from wild spawns in Sinaloa, Mexico, in 1989 (Wyban et al. 1993, Pruder et al. 1995). The stock has been referred to as USMSFP Mexican strain (Brock et al. 1995, 1997, Hasson et al. 1995), USMSFP Population 1 (Carr et al. 1997), or USMSFP Kona stock (Soto \& Lotz 2001, Lotz et al. 2003). This stock is very susceptible to TSV infection (Brock et al. 1995, 1997, Pruder et al. 1995). We used an isolate of TSV obtained from Texas, USA, in 1995, and it corresponds to the TSV-A serotype of Erickson (2002). All shrimp used were from 1 to $3 \mathrm{~g}$.

To obtain shrimp with chronic infections, we exposed uninfected shrimp per os to a single $3 \%$ body weight dose of cephalothoraces infected with TSV in 10001 tanks. Shrimp were fed commercial pellets twice daily from Days 1 to 10 and once daily from Days 11 to 21. Mortality subsided after 10 to $14 \mathrm{~d}$ and shrimp surviving to $21 \mathrm{~d}$ were considered chronically infected. Uninfected controls were obtained by the same procedure except they were fed uninfected cephalothoraces.

The water used in all trials was pumped from Davis Bayou (Mississippi) and disinfected twice with bleach (28 ppm). A common stock of 24 ppt seawater was prepared by the addition of artificial sea salt (Crystal Sea Marinemix ${ }^{\circledR}$ ). In order to obtain lower salinities, tap water was added. Tap water was dechlorinated by letting it age overnight before use. Salinity was measured with a hand refractometer.

Shrimp were stocked individually in 2 1 containers with the appropriate salinity. Each container was equipped with a lid to prevent shrimp from escaping. All containers were placed in a water bath and each was supplied with aeration by 1 air line attached to an electric air pump. The temperature of the water bath was maintained at $28 \pm 1^{\circ} \mathrm{C}$ with a submersible electric heater.

We performed 3 trials to compare tolerance to rapid salinity drop of Litopenaeus vannamei with chronic TSV infections to that of shrimp with no infections. In all trials, 10 shrimp of each kind were used at each salinity. The first trial consisted of the direct transfer of chronically infected and uninfected shrimp from a salinity of 24 ppt into seawater of $6,12,18$ and $24 \mathrm{ppt}$. The second trial consisted of the direct transfer of chronically infected and uninfected shrimp into seawater of $0,3,6,12$ and 24 ppt. The third trial consisted of the direct transfer of the uninfected and chronically infected shrimp into seawater of $0,3,6,9,12$ and $24 \mathrm{ppt}$. Shrimp in 24 ppt served as a negative controls.

The time of death of each shrimp was recorded. During each trial all dead or moribund shrimp were fixed in Davidson's fixative as described by Bell \& Lightner (1988). At the end of $6 \mathrm{~d}$, all surviving shrimp were fixed. After fixation, shrimp were embedded in paraffin, sectioned at $4 \mu \mathrm{m}$ thickness, and stained with hematoxylin and eosin. Shrimp were examined histologically and by in situ hybridization (TSV-in situ ShrimProbe ${ }^{\text {TM }}$, DiagXotics) for the presence of TSV lesions. Statistical analyses were performed using the SYSTAT 10 (SPSS). Alpha level was set to 0.05, and Bonferroni's correction was used where appropriate. Logistic equations were fit by least squares. Survival analysis was implemented as a Cox proportional hazard model.

\section{RESULTS}

Survival analysis detected a significant effect of salinity drop on survival $(p<0.0001)$ as well as a difference in survival among trials $(p=0.0003)$. Shrimp with chronic TSV infections had lower survival than uninfected shrimp $(p=0.005)$.

Table 1 presents the results for salinity drops from $24 \mathrm{ppt}$ for infected and uninfected shrimp. For salinity

Table 1. Litopenaeus vannamei. Percent 6 d survival and mean survival time (d) of chronically Taura syndrome virus (TSV)-infected and uninfected shrimp transferred from $24 \mathrm{ppt}$ salinity to lower salinities

\begin{tabular}{|c|c|c|c|c|c|c|}
\hline \multirow{2}{*}{$\begin{array}{l}\text { Salinity } \\
\text { (ppt) }\end{array}$} & \multicolumn{3}{|c|}{$\ldots$ TSV negative } & \multicolumn{3}{|c|}{$\ldots$ TSV positive } \\
\hline & $\begin{array}{c}\text { \% survival } \\
\text { (95\% CI) }\end{array}$ & $\begin{array}{l}\text { Mean survival } \\
\text { time (SEM) }\end{array}$ & $\mathrm{n}$ & $\begin{array}{c}\text { \% survival } \\
\text { (95\% CI) }\end{array}$ & $\begin{array}{l}\text { Mean survival } \\
\text { time (SEM) }\end{array}$ & $\mathrm{n}$ \\
\hline 0 & $\begin{array}{c}0.00 \\
(0.00-0.20)\end{array}$ & $\begin{array}{c}0.5 \\
(0.11)\end{array}$ & 20 & $\begin{array}{c}0.00 \\
(0.00-0.20)\end{array}$ & $\begin{array}{c}0.5 \\
(0.11)\end{array}$ & 20 \\
\hline 3 & $\begin{array}{c}0.50 \\
(0.23-0.74)\end{array}$ & $\begin{array}{c}4.5 \\
(0.44)\end{array}$ & 20 & $\begin{array}{c}0.10 \\
(0.00-0.34)\end{array}$ & $\begin{array}{l}2.75 \\
(0.52)\end{array}$ & 20 \\
\hline 6 & $\begin{array}{c}0.87 \\
(0.65-0.97)\end{array}$ & $\begin{array}{c}5.2 \\
(0.37)\end{array}$ & 30 & $\begin{array}{c}0.40 \\
(0.20-0.61)\end{array}$ & $\begin{array}{c}3.93 \\
(0.37)\end{array}$ & 30 \\
\hline 9 & $\begin{array}{c}1.00 \\
(0.65-1.00)\end{array}$ & $\stackrel{-}{(0.45-1.00)}$ & 10 & $\begin{array}{c}0.90 \\
(0.28)\end{array}$ & $\begin{array}{l}5.7 \\
10\end{array}$ & 10 \\
\hline 12 & $\begin{array}{c}0.967 \\
(0.78-1.00)\end{array}$ & $\begin{array}{l}5.85 \\
(0.15)\end{array}$ & 30 & $\begin{array}{c}0.767 \\
(0.54-0.91)\end{array}$ & $\begin{array}{c}5.57 \\
(0.19)\end{array}$ & 30 \\
\hline 18 & $\begin{array}{c}0.90 \\
(0.45-1.00)\end{array}$ & $\begin{array}{c}5.8 \\
(0.19)\end{array}$ & 10 & $\begin{array}{c}0.90 \\
(0.45-1.00)\end{array}$ & $\begin{array}{c}5.6 \\
(0.38)\end{array}$ & 10 \\
\hline 24 & $\begin{array}{c}0.933 \\
(0.73-0.99)\end{array}$ & $\begin{array}{c}5.85 \\
(0.15)\end{array}$ & 30 & $\begin{array}{c}1.00 \\
(0.87-1.00)\end{array}$ & $\begin{array}{l}- \\
-\end{array}$ & 30 \\
\hline
\end{tabular}




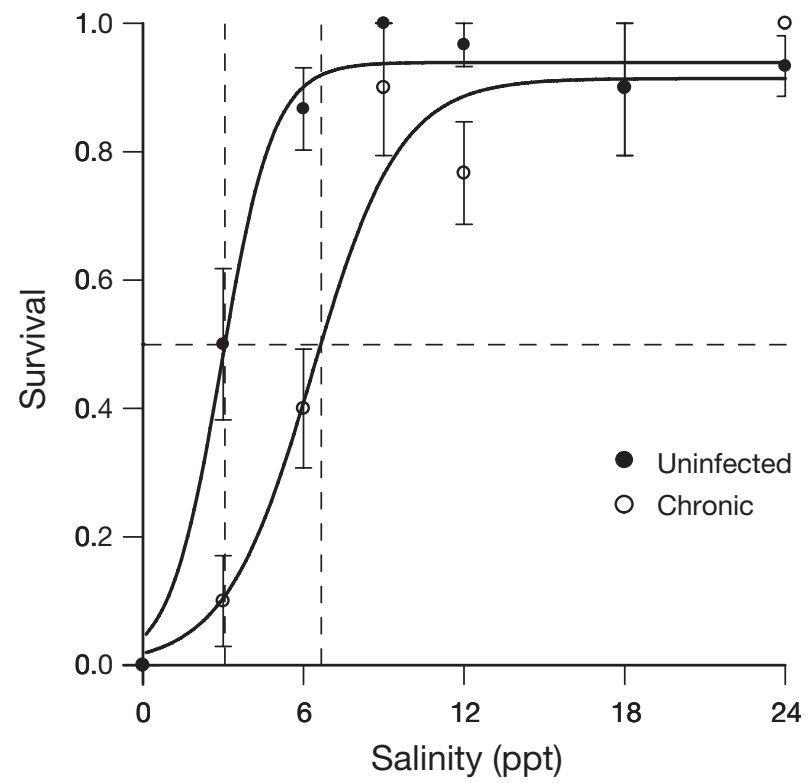

Fig. 1. Litopenaeus vannamei. Proportion of chronically TSV-infected and uninfected shrimp surviving exposure to different salinities. Data points: mean $( \pm \mathrm{SE})$ survival for all trials; curves: least squares, best fit logistic equations to observed survivals; vertical dashed lines: salinities at which $50 \%$ of uninfected (left line) and infected (right line) shrimp died by Day 6 ; hoziontal dashed line: $50 \%$ survival

drops to 0, $6 \mathrm{~d}$ survivals were 0.00 for both infected and uninfected shrimp. For drops to 12,18 and $24 \mathrm{ppt}$ there were no differences between survival of infected and uninfected shrimp (Bonferroni corrected chi-square test). For drops to salinities of 3 and $6 \mathrm{ppt}$, uninfected shrimp had statistically higher survival than chronically infected shrimp (Bonferroni corrected chi-square test).

Fig. 1 displays the least squares fits of the logistic function to $6 \mathrm{~d}$ survivals after various salinity drops for infected and uninfected shrimp. The salinity at which $50 \%$ of the uninfected shrimp $\left(\mathrm{LC}_{50}\right)$ died by Day 6 was 3.06 (95\% confidence interval 2.55 to 3.57 ). The $\mathrm{LC}_{50}$ salinity for the chronically infected shrimp was $6.65 \mathrm{ppt}$ (95\% confidence interval 5.76 to 7.55 ).

Histology and in situ hybridization analyses were performed on 18 chronically infected shrimp that died or were moribund and 19 uninfected shrimp. Histological examination revealed that all chronically infected shrimp analyzed had spheroids in their lymphoid organ, and in situ hydridization that the lymphoid organs were TSV positive. None of the chronically infected shrimp displayed acute lesions that would indicate a relapse to an acute disease state prior to death. None of the negative control shrimp that were examined by histology or in situ hybridization displayed any sign of TSV.

\section{DISCUSSION}

The results suggest that Litopenaeus vannamei with chronic TSV infection are not as vigorous as uninfected shrimp. Under the same conditions of reduced salinity, chronically infected shrimp had lower survival than uninfected shrimp. Moreover, the salinity in which $50 \%$ of the chronically infected shrimp died by Day 6 was 3.06 ppt whereas for uninfected shrimp the $\mathrm{LC}_{50}$ was 6.65 ppt. It is likely that under other adverse environmental conditions chronically infected shrimp would also have a survival that is lower that uninfected shrimp. Other disturbances such as change in temperature and handling have been shown to cause increased mortalities in Penaeus monodon, Marsupenaeus japonicus and Fennerpenaeus penicillatus infected with WSSV (Chou et al. 1995). In addition, Chen et al. (1989) suggested that crowding could initiate pathogenesis in $P$. monodon and $F$. penicillatus when exposed to Monodon baculovirus (MBV).

The consequences of sublethal infections have been studied in other arthropods. Stuck \& Overstreet (1994) studied the sublethal effects of Baculovirus penaei on growth and survival in postlarval Litopenaeus vannamei, and demonstrated that surviving shrimp displayed a significant reduction in weight during the first 4 wk of infection. In the Indian meal moth Plodia interpunctella, it has been shown that infections with granulosis virus may be carried throughout development in a pre-symptomatic form that reduces egg production and egg viability (Sait et al. 1994).

One hypothesis for lower tolerance to salinity drop is that, upon stress, shrimp with chronic TSV infections relapse to an acute TSV stage and then die. However, none of the chronically infected shrimp that died in our study displayed histological evidence of acute infection. A second more likely hypothesis is that chronically infected shrimp have not fully recovered from the disease and there remains a cost associated with carrying the virus in the chronic state.

Although, uninfected Litopenaeus vannamei can be cultivated successfully at salinities as low as 0 ppt ( $\ll 1$ ppt) and 2 ppt (Chauvin 1983, Wulff 1987), sudden decreases in salinity, e.g. after heavy rain, have been linked to outbreaks of TSV in shrimp farms (Wigglesworth 1994, Lightner et al. 1995). The reason for this may be that chronically infected shrimp carrying TSV die after the salinity drops associated with rainfall. Once dead, uninfected shrimp eat them, causing an epidemic to ensue.

Acknowledgements. This study was funded in part by grant numbers 98-38808-6019 and 2002-38808-01381 from the Cooperative State Research Education and Extension Service of the United States Department of Agriculture. 


\section{LITERATURE CITED}

Bell TA, Lightner DV (1988) A handbook of normal penaeid shrimp histology. World Aquaculture Society, Baton Rouge, LA

Brock JA, Gose R, Lightner DV, Hasson KW (1995) An overview on Taura syndrome, an important disease of farmed Penaeus vannamei. In: Browdy CL, Hopkins JS (eds) Swimming through troubled water. Proceedings of the Special Session on Shrimp Farming. World Aquaculture Society, Baton Rouge, LA, p 84-94

Brock JA, Gose RB, Lightner DV, Hasson K (1997) Recent developments and an overview of Taura syndrome of farmed shrimp in the Americas. In: Flegel TW, MacRae IH (eds) Diseases in Asian aquaculture, III. Asian Fisheries Society, Manila, p 275-283

Carr WH, Fjalestad KT, Godin D, Swingle J, Sweeney JN, Gjedrem T (1997) Genetic variation in weight and survival in a population of specific pathogen-free shrimp, Penaeus vannamei. In: Flegel TW, MacRae IH (eds) Diseases in Asian aquaculture, III. Asian Fisheries Society, Manila, p 265-271

Chauvin WD (1983) Ecuador: shrimp moves to second largest export. Fish Boat p 41-70

Chen SN, Chang PS, Kou GH (1989) Observation on pathogenicity and epizootiology of Penaeus monodon baculovirus (MBV) in cultured shrimp in Taiwan. Fish Pathol 24:189-195

Chou HY, Huang CY, Wang CH, Chiang CH, Lo CF (1995) Pathogenicity of a baculovirus infection causing white spot syndrome in cultured penaeid shrimp in Taiwan. Dis Aquat Org 23:165-173

Erickson HS (2002) Characterization of Taura syndrome virus (TSV) isolates from penaeid shrimp: pathology, virulence, structural protein analysis and genetic diversity \& development of the aquaculture pathology diagnostic laboratory database. $\mathrm{PhD}$ dissertation, University of Arizona, Tucson, AZ

Hasson KW, Lightner DV, Poulos BT, Redman RM, White BL, Brock JA, Bonami JR (1995) Taura syndrome in Penaeus vannamei: demonstration of a viral etiology. Dis Aquat Org 23:115-126

Hasson KW, Lightner DV, Mari J, Bonami JR, Poulos BT, Mohney LL, Redman RM, Brock JA (1999a) The geographic distribution of Taura syndrome virus (TSV) in the

Editorial responsibility: Timothy Flegel,

Bangkok, Thailand
Americas: determination by histopathology and in situ hybridization using TSV-specific cDNA probes. Aquaculture 171:13-26

Hasson KW, Lightner DV, Mohney LL, Redman RM, Poulos BT, White BM (1999b) Taura syndrome virus (TSV) lesions development and the disease cycle in the Pacific white shrimp Penaeus vannamei. Dis Aquat Org 36:81-93

Lightner DV (1999) The penaeid shrimp virus TSV, IHHNV, WSSV, and YHV: current status in the Americas, available diagnosis methods, and management strategies. J Appl Aquacult 9:27-52

Lightner DV, Redman RM, Hasson KW, Pantoja CR (1995) Taura syndrome in Penaeus vannamei (Crustacea: Decapoda): gross signs, histopathology and ultrastructure. Dis Aquat Org 21:53-59

Lotz JM, Flowers AM, Breland V (2003) A model of Taura syndrome virus (TSV) epidemics in Litopenaeus vannamei. J Invertebr Pathol 83:168-176

Pruder GD, Brown CL, Sweeney JN, Carr WH (1995) High health shrimp systems: seed supply-theory and practice In: Browdy CL, Hopkins JS (eds) Swimming through troubled water. Proceedings of the Special Session on Shrimp Farming. World Aquaculture Society, Baton Rouge, LA, p 40-52

Sait SM, Begon M, Thompson DJ (1994) The effect of a sublethal baculovirus infection in the Indian meal moth, Plodia interpunctella. J Anim Ecol 63:541-50

Soto MA, Lotz JM (2001) Epidemiological parameters of white spot syndrome virus (WSSV) infections in Litopenaeus vannamei and L. setiferus. J Invertebr Pathol 78:9-15

Stuck KC, Overstreet RM (1994) Effect of Baculovirus penaei on growth and survival of experimentally infected postlarvae of the Pacific white shrimp, Penaeus vannamei. J Invertebr Pathol 64:18-25

Wigglesworth J (1994) Taura syndrome hits Ecuador farms. Fish Farmer Magazine (May/June):30-31

Wulff R (1987) Rumblings in Arizona. In: Rosenberry B (ed) World shrimp farming 1987. Aquaculture Digest, San Diego, CA, p 10-11

Wyban JA, Swingle JS, Sweeney JN, Pruder GD (1993) Specific pathogen-free Penaeus vannamei. World Aquacult 24:39-45

Yu CI, Song YL (2000) Outbreak of Taura syndrome in Pacific white shrimp Penaeus vannamei cultured in Taiwan. Fish Pathol 35:21-24

Submitted: August 29, 2003; Accepted: March 8, 2005 Proofs received from author(s): May 30, 2005 